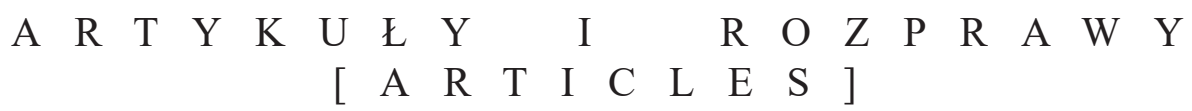

KATALIN RESZEGI

DOI: http://dx.doi.org/10.17651/ONOMAST.64.4

https://orcid.org/0000-0002-4443-3284

Onomastica LXIV, 2020

kataszakall@gmail.com

University of Debrecen

Debrecen, Hungary

\title{
TOPONYMS AND SPATIAL REPRESENTATIONS ${ }^{1}$
}

Keywords: toponyms, cognitive map, linguistic relativity

\section{INTRODUCTION}

The human mind creates representations of the spatial environment. The organization of these spatial representations in the mind is referred to as a cognitive or mental map. In cognitive psychology, both terms refer to "an individual's knowledge of spatial and environmental relations, and the cognitive processes associated with the encoding and retrieval of the information from which it is composed" (Kitchin \& Blades, 2002, p. 1). ${ }^{2}$ This inner map helps us to orient ourselves in space. ${ }^{3}$ The cognitive map is closely associated with language in several ways: through the expression of spatial relations, the designation of spatial categories (geographical common nouns), the linguistic aspects of the frame of reference used for orientation, and finally, through the toponyms designating specific places and spatial objects. The first three of these aspects have received significant scholarly attention from linguists, psychologists, psycholinguists and are also often

${ }^{1}$ This paper was supported by the János Bolyai Research scholarship of the Hungarian Academy of Sciences and the ÚNKP-2020-5 New National Excellence Program of the Ministry for Innovation and Technology. It was carried out as part of Research Group on Hungarian Language History and Toponomastics (University of Debrecen-Hungarian Academy of Science).

${ }^{2}$ In geography, however, a mental map is often determined as an actual manifestation (usually a drawing) of this perceived knowledge (for the terminological issues see Kitchin, 1994, pp. 1-5). Based on this distinction, cognitive mapping is the implicit, while mental mapping - the explicit part of the same process.

${ }^{3}$ For the neural background of the cognitive map see O'Keefe, 1976; Ekstrom et al., 2003. Considering the complexity of spatial representations, psychologists suggest that the cognitive map is not limited to finding our way and orientation, but it may also be interpreted as a more general cognitive and symbolic set of knowledge (Dúll, 2007, p. 140; Kitchin, 1994).

This is an Open Access article distributed under the terms of 
mentioned as an argument supporting linguistic relativity (Lukács, Szamarasz, 2014; Pederson, 2007; Boroditsky, 2006, 2009, 2011; Burenhult, Levinson, 2008; Levinson et al., 2002). The role of toponyms in the construction of spatial representation, however, has rarely been addressed in such research.

More recently, however, scholars have expressed the need to study the relationship between toponyms and spatial representations in onomastics (Reszegi, 2012, 2020b; Győrffy, 2017; Varga, 2020). Meanwhile, the same need is also visible from the perspective of other disciplines, primarily anthropology (Hunn, 1996; Kari, 1989; Maffi, 2002; Haviland et al., 2011, p. 355). Such research projects rely on a more extensive scholarly perspective and it is claimed that toponyms are not simply labels that identify certain points of space but portals of social change, history, and the use and perception of the environment; as such, they contain facts, reflect hidden landscapes, and have political power and significance. Thus the study of toponyms reveals a lot about the language, values and beliefs of a community, the environment, economy, and history, as these linguistic elements reflect the basic relationship between people and their residence as well as their encyclopaedic knowledge of the area (Basso, 1988, p. 103).

This paper has a double aim. It attempts to highlight the relationship between toponyms, spatial perception, and cognitive maps. Besides, it also addresses the issue whether we can talk about linguistic relativity in connection with toponyms. As it is known, linguistic relativity is a general term used to refer to two basic notions about the relationship between language and thought. The first notion is that languages are relative, that is, they convey reality in different ways. The second notion is that the linguistic expression of concepts has some degree of influence over the way we think about reality (cf. Pederson, 2007, p. 1012). Although I refer to the first interpretation of linguistic relativity in relation to toponyms, the focus of this paper is on the second notion, that is, the idea that language use might influence thought. Based on this, I analyse whether the toponyms used by a certain group of people and related to a given language influence how language users perceive their environment and if there are general linguistic-cultural differences in this regard. This research question is slightly different from modern research topics of linguistic relativity studies that usually try to answer the question whether the choice of particular linguistic expressions may influence the non-linguistic representations of concepts (Pederson, 2007, p. 1013). I focus on the general linguistic features of toponyms in different societies and their possible influence on spatial behaviour.

The nature of this topic requires an interdisciplinary approach, hence findings from different areas of cognitive science (cognitive psychology, 
cognitive linguistics, ${ }^{4}$ psycholinguistics) and social sciences (anthropology, socio-onomastics) are taken into consideration. Based on them, I first present an overview of the mental representation of names and spatial information (section 2), which is followed by the comparison of the name model and spatial knowledge of modern society and traditional communities ${ }^{5}$ based on anthropological and socio-onomastic literature (sections 3,4). Although, considering the complexity of the research question, this overview cannot deal with all the possible relevant aspects of the name models and the cognitive maps of the different societies, and obviously even within these two types of societies differences could be accounted for by the features of usage of space and toponyms (even the distinction between traditional and modern societies is supposedly not in fact so sharp in that regard), the comparison can still be used to draw some preliminary conclusions (section 5).

\section{MENTAL REPRESENTATION OF NAMES AND SPATIAL INFORMATION}

According to the network-based approach of the mind, language is an integral part of the cognitive system perceived as a network and it is not isolated from other cognitive functions (Harris, 2006). The individual as a child in the early stage of learning about the world stores the experienced and processed information (mental representation) in the form of holistic patterns and to some extent this aspect of the cognitive system is preserved later on as well. In a mental system, language - including toponymic representations making up part of the mental lexicon (toponomasticon, onomasticon within mental lexicon, cf. Nyström, 2016; Reszegi, 2020b) — and spatial representations are related to one another. Networks representing spatial information are therefore in contact with networks representing toponyms by means of information related to certain objects of the space, or more precisely they also make up a part of spatial representations. From another perspective, representations of toponyms are also embedded in the complete knowledge system of the individual, and they may be imagined as a network of sets of processed and stored information about the reference object(s) and (phonological, morphological, syntactic) characteristics related to the word.

\footnotetext{
${ }^{4}$ Cognitive linguists do not have a common opinion on linguistic relativity (cf. Pederson, 2007, pp. 1028-1029).

${ }^{5}$ These terms are generally used — and also debated — in social sciences. In anthropology, the term traditional society - often construed as indigenous or tribal people — refers to societies that are small-scale, and are derived from indigenous and often ancient cultural practices. It is contrasted with a modern, changing, industrial society.
} 
The establishment and survival of the relationship between the cognitive map and language is also facilitated by the fact that beyond physical perceptions linguistic stimuli also play a role in the creation of spatial representation; when people grow up they also hear discussions about space and certain spatial information are in some cases built into their cognitive maps by means of linguistic mediation only. ${ }^{6}$ Speech also plays an important role by means of articulating spatial information, in this way approximating the individual cognitive maps exhibiting differences due to processes of categorization and personal experiences.

The two-directional relationship is also reflected in the idea that the actual organization of the cognitive map determines language use about the area. This is especially important since with the study of linguistic data (including the use of toponyms), we may draw conclusions about the cognitive structures influencing spatial orientation and the process of cognitive mapping. The view of space and the cognitive map of the name-giver also influences the creation of toponyms, therefore by studying toponyms, we may understand the spatial perception of name-givers. At the same time, such a relationship is mutual: both toponyms and discussions about the space influence the spatial perception of name users (Regier, 1996; Reszegi, 2012, pp. 96-97; for a more general overview see Schemmel, 2016).

The role and weight of toponyms in the development of spatial perception might be influenced by the fact whether they are stored as elements of the mental lexicon holistically or analytically. In terms of the acquisition of toponyms and their representation in the mental lexicon, cognitive linguistics presupposes holistic storage instead of analytical processing. Toponyms are linguistic units, which means that we learn and store them basically without analytical processing, without specific attention to their individual parts or their arrangement, ${ }^{7}$ i.e., a unit is a cognitive routine and analytical processing may contribute to unit-based processing only in a secondary manner (Tolcsvai Nagy, 2008, p. 37; Langacker, 1987, pp. 57-76). ${ }^{8}$ We only need to consider a certain degree of analytical processing

${ }^{6}$ Downs and Stea consider the indirect, vicarious spatial information - verbal and written descriptions, cartographic maps etc. - and the spatial representation based on them similar in function to direct sensory experience of the environment, yet in form they are assumed to be different since they reflect different aspects (2011, p. 316; Gyselinck \& Meneghetti, 2011). For the specific human ways of cultural learning see Tomasello, 1999.

${ }^{7}$ It means that a compound name for example (e.g. the Hungarian Sárospatak town name) is processed without paying attention to its elements (sáros 'muddy' + patak 'river').

${ }^{8}$ The unit-based nature of names is also related to the issue of the models of the mental lexicon and the manner of grammatical analysis, i.e., how the processing and storage of complex word forms take place. Based on studies of common nouns, more recently those models are determining within psycholinguistics that somehow mix the analytical and the holistic approach (Lukács et al., 2014, pp. 225-227). However, the findings of studies supporting the analytical operation may also be explained with a holistic mental lexicon that fundamentally works on an analogical basis (J. P. Blevins, J. Blevins, 2009). It is difficult to explain the isolated set of grammar rules from the evolutionary 
and analogical correspondence when learning names. In the case of the already-established forms, unit-based processing makes both the understanding of and the production of names effective (Langacker, 1987, pp. 57-76). According to onomasticians, however, based on naive name explanations, among others, we might account for analytical processing even in the case of known names (Reszegi, 2009, p. 12; Hoffmann, 2012, pp. 20-21; for a psycholinguistic point of view see Lukács et al., 2014, pp. 225-227). This, of course, depends on the linguistic susceptibility of the individual and their former experience with toponyms, how motivated the names they have encountered are in general, the linguistic structure of the names acquired etc., i.e., the general knowledge of toponyms, the so-called name model.

The name model and name competence include the speakers' mental representations of specific names along with the knowledge and patterns (schemas) that can be generalized on the basis of analogy. The schemas emerge from specific names: connections are established between the networks mapping the names by means of shared elements of knowledge and these links represent the schemas. The name model contains knowledge about the semantic features, the (morphological/lexical) structures of toponyms, the name-giving methods, and how frequent these characteristics are (in general and in the case of names of different place categories). Such knowledge about names also affects our attitude towards names, how we process them, and what kind of expectations we have towards them (Hoffmann, 1993; Reszegi, 2015, p. 166). The name models of individuals from a given community could be similar because of their similar, partly overlapping toponymic awareness - that is why the term could also be used on the level of a group. The name model could be different in different languages.

Based on the outlined relationship between the mental representation of names and spatial information, it can be supposed that linguistic features of toponyms and their general morphological-semantic structure might have an effect

perspective and the holistic type of storage seems much more solid from the aspect of ontogenesis too (Nánay, 2000, p. 130; Tuggy, 2005; Tomasello, 2009). Holistic storage, however, does not necessarily mean that we need to store all possible word forms, these holistic patterns (according to their similarities to one another and their environment) are gradually divided into morphemes in the process of first-language acquisition and they are arranged into dynamic formal-syntactic groups. The formal and syntactic organizing principles within the lexicon may be correlated with grammar in the traditional sense. Thus, we may see some degree of analysis even in the holistic models, i.e., analogical correlations, but these are not (necessarily) conscious processes (Bybee \& Slobin, 1982; Tomasello, 2009). In the case of personal names, the semantics-based speech errors and the priming tests indicate a similar type of analytical processing, according to which the word presented as a family name automatically activates the semantics of its appellative pair also (Valentine et al., 1996, p. 72). A similar kind of operation may be supposed in the case of toponyms too. Thus, the representation of names is closely associated with the representation of numerous other names and common nouns based on perspectives of phonology, phonetics, name structure, semantics, co-occurrence, etc. A part of these relations represents similarities to other names and common nouns. 
on spatial representations, that is, the assumption of linguistic relativity in connection with toponyms might be relevant. In the next part of the paper this question is addressed on the basis of specific case studies.

\section{COGNITIVE MAPS AND TOPONYMS IN MODERN SOCIETIES}

In modern societies, human horizons have expanded significantly due to the transportation opportunities available for everyone, and we also have direct and indirect knowledge even about other continents and far-away regions thanks to education and the media. At the same time, however, due to the changing lifestyles resulting from the wide-ranging use of technical devices, the majority of the people have moved away from nature and the surrounding geographical landscape. Daily life is connected to residential areas, most people have little knowledge about the outskirts of settlements, on our cognitive maps the border is mostly unfinished and full of blank spots (Reszegi, 2018, 2020b).

As a result, most people also have a limited knowledge of toponyms and the known onomastic corpus has a different composition in terms of the proportion of various toponyms than one or two hundred years ago. As revealed by the most recent studies in Hungarian socio-onomastics, ${ }^{9}$ the names known by everyone represent only $1-5 \%$ of the total onomastic corpus of a given settlement even in the case of smaller villages. Although in terms of the core onomastic corpus (the names that are known by at least $70 \%$ of respondents) this proportion is significantly higher (30-64\% in the examined settlements), these are mostly names related to inner areas, which designate more important, central places (Györffy, 2017, p. 101). It is a major methodological consequence of this fact that we need to exercise caution when considering the findings of studies that draw conclusions about spatial knowledge based on toponyms, as these cannot be generalized even onto the community studied, not to mention any larger-scale attempts. It is obvious, however, that besides the onomastic corpus of their own place of living, people have the knowledge of numerous other places and their names, and these also form a part of their cognitive maps and the sub-network of toponyms (Reszegi, 2015).

Moreover, in these societies, the speakers have an experience (name model) of toponyms according to which the semantically non-transparent names are present in the name system in a larger proportion (for example, the etymologies of names like Debrecen, Budapest, Balaton are more or less explained but not necessarily known to an average person, street names in Hungarian are not generally descriptive either). Besides, in the process of their linguistic socialization, individuals soon

${ }^{9}$ In this section, research results mainly on the Hungarian name-usage are overviewed, but basically similar name-usage patterns might exist in other modern societies. 
realize that semantically transparent names do not necessarily reflect the features and nature of the landscape (e.g. Sárospatak 'muddy river' is a town name; Hoffmann, 2012, pp. 23-24). ${ }^{10}$ Thus it is not an expectation towards names that they should reflect the actual features of the environment. From another perspective, the semantic content present in the names does not necessarily affect the spatial knowledge of the name user, at least not directly. In those people's cognitive system whose toponomasticons contain mostly non-transparent or non-descriptive names, these toponyms could be connected as labels to the representations of places and cannot be used to form specific expectations relating the designated places.

Based on such experience, the name-user considers the identifying function of names to be more dominant; thus, the linguistic structure and the comparison of the semantic content of the name elements and the actual landscape seem less important. This theoretical idea is confirmed by socio-onomastic interviews conducted by Erzsébet Györffy, as the respondents first referred to the place designated by the name and the events related to the place in all cases. At the same time, as her findings show, the analytical processing of names is not necessarily typical. During her fieldwork conducted in Tépe (a small village in the eastern part of Hungary) one respondent, for example, answered the question of why the name of Békás 'abundant in frogs' could serve as the name of the given area by claiming that she had never thought about it, and only later added that it must have been named after frogs (2017, p. 106). Based on socio-onomastic interviews, this kind of linguistic behaviour does not seem unusual in the least. Thus, in terms of contemporary name usage, the approach of cognitive semantics seems to be well founded and we can talk about names as units. So far, however, it is not clear how typical this attitude is for name users but it seems certain that it may not be generalized. Nevertheless, another example by Györffy is testament to the analysis of names and their analogical correspondence, and indicates that name users are also aware of connections between names. Speakers, being aware of the names of Bika-legelö 'bull pasture', Bika-kút 'bull well', Bika-erdö 'bull forest' and the location of the objects denoted by the names next to one another, located the name of Bika-zug 'bull corner' (unknown or little-known to them) next to these, even though the designated place actually is not one they are familiar with (2015, p. 32). This kind of linguistic behaviour is also corroborated by other socio-onomastic investigations. Speakers in Szalárd (a small village in north-western part of Romania), for example, located unknown Dóci-rét < Dóci family name + 'meadow'

${ }^{10}$ In connection with this issue, we need to be aware that the motivation of names and the semantic content present in them provide information on the conditions at the time of name-giving, which means that even if an analogical link is made for the names, this is directed by the speaker's knowledge of names and the knowledge of the current attributes of the area, and the two do not necessarily correspond to each other. 
and Sziki-kút < family name + 'spring' names close to the neighbouring village where the mentioned families live using their knowledge about the residences of those families (Varga, 2020, p. 28).

The example quoted in connection with Békás indicates that we do not need to rely on analytical processing in modern societies even in the case of transparent names. In line with this, even those using the names do not necessarily link the content present in the names with the features of the area, thus the name does not influence their landscape perception. ${ }^{11}$ We need to emphasize, however, that there is a need for further research to determine how general this kind of linguistic behaviour could be. Besides, we also might suppose that there are possible individual differences in this regard. Based on my interviews with people having a varied knowledge of names, I believe that we can expect to see significant individual differences not only in terms of the knowledge of names but also in the attitude towards them.

As psychological experiments (cf. Valentine et al., 1996, p. 72) show, some sort of analogical analysis, an analogical correspondence of names, takes place even in entrenched unit-like proper names, even if this is not conscious, similarly to the acquisition and processing of different common nouns that are not learned and processed by means of a conscious analysis either. The question is if all this counterbalances the knowledge of the speaker concerning the fact that names do not need to reflect the actual attributes of the place. In this regard, we can obviously expect to encounter individual differences also.

In light of all this, it is worth reconsidering an old view that people use toponyms primarily to facilitate spatial orientation (cf. e.g., Lörincze, 1947, p. 3; Balázs, 2008, p. 349). Toponyms facilitate orientation indirectly, and only if the people trying to orientate themselves already have some kind of a familiarity with the area that is not based solely on linguistic experience. Thus, toponyms do not enable orientation directly, but their most fundamental role is rather to make the designation of a given area easier and more obvious for members of a given community (Reszegi, 2012).

\section{COGNITIVE MAPS AND TOPONYMS IN TRADITIONAL SOCIETIES}

The characteristics of name usage in Western societies and the conclusions drawn from them regarding the mental representation of names (as it is related to an industrial lifestyle) clearly cannot be used to make general statements extended in

\footnotetext{
${ }^{11}$ It does not mean that names are not important for people, because they could play a part in building their identity.
} 
space or time. In order to obtain more detailed insights into these issues, we also need to examine the name-usage patterns of communities with a different lifestyle. To do so, the so-called traditional societies will be the focus of the following part of the paper. Although globalization influences these communities to an increasing extent, which in turn results in a change of lifestyle (on the impact of globalization on spatial knowledge see the papers of Lovis \& Whallon, 2016; on the general effects of globalization on indigenous cultures see e.g. Coates, 2004), some of these societies have only been affected for the last few decades, while for many others this impact began decades or a century ago. Nevertheless, to get closer to the so-called traditional name model and spatial knowledge, we can rely on former anthropological and anthropological linguistic research.

Stephen C. Jett $(2011,2014)$, as well as Klara Kelley and Harris Francis (1994), examined the geographical knowledge of the Navajo and found that myths and traveling played an important role in the life of the community. They also connected the routes and activities of mythological heroes to the landscape with toponyms. In this way, the associated stories and descriptive names served as mnemonic aids for the Navajos travelling long distances. Toponyms and topography important in mythical stories appeared in songs, tales, and prayers, connecting people in this way to the landscape. This community had no written culture, ${ }^{12}$ so these stories served practically as maps guiding the Navajo to places of hunting and gathering. Thus, their ceremonial stories included a kind of verbal map, identifying the routes, points of orientation, and cultural landmarks. The order of these stories served as a guidebook for travellers so that they could know which places they needed to reach, in which order and from which direction. According to anthropologists, stories may not only work as maps but they were actually used this way in the past (Francis \& Kelley, 2005, pp. 98-99). As part of these stories, names are like street signs, and hunters and gatherers rely on them for orientation (Nelson, 1983, p. 39).

Cogos, Roué and Roturier introduced the system of spatial orientation of the Sami people: they studied the toponyms of a Sami reindeer herding community, their knowledge of toponyms, the role of toponyms in the daily life of herders, along with their map usage (2017). Traditionally, the Sami do not use maps for orientation, they do not make maps themselves, and even today they use maps very rarely. As one of the respondents said: "We found [our way] better without maps! [laughter] We didn't need any. What will you do with a map when you have the ponds, and the sunlight? And the rivers.... The brooks flow from west to east. And the trees thrive towards the sun. [a woman, Sirges community]" (2017, p. 45).

${ }^{12}$ Literacy in Navajo is still not widespread: Navajos are usually literate in English, not in Navajo (cf. Webster, 2017, p. 240). 
Instead of this, they developed their own method of navigation and of passing through a given area. Narratives, storytelling, and travel accounts play an especially important role in their daily discussions. When they are talking about places they have visited or will visit, they use the method of cognitive mapping, which is organized around the named points of orientation, often connected to those pieces of information that relate what kind of opportunities they provide for the herders. The named points of orientation are part of the micro-perspective: hillocks, striking spatial formations, stones, bushes, etc. In this non-written map toponyms play a crucial role, or as a member of the group said: "in the past the name was the map." (2017, p. 45). For the Sami people, toponyms provide the basis for the transfer of cultural knowledge related to the landscape. According to researchers, toponyms really formed a cognitive map by means of storytelling, which played a major role in the life of the community. The passing of toponyms from one generation to another is inseparable from oral mapping with the use of narratives. During their wanderings, leaders show the typical landmarks serving as points of orientation, they mention their names and possibly also tell stories related to them. Members of the group even talk about time this way: they link the period discussed to one of the journeys. Then these maps help them recall the characteristics of the landscape and stimulate communication organized around toponyms (2017, pp. 45-46).

The rich association of toponyms, their relation to the narrative and belief system can be found among other native peoples too (cf. e.g. the Blackfoot of the Northern Plains in America, see Oetelaar, 2016; the Igloolik in the Eastern Canadian Arctic, see Aporta, 2016; the Eipo in Papua New Guinea and Dene Chipewyan in Western Canada, see Thiering \& Schiefenhövel, 2016, Thiering, 2015; the Ulgunigamiut in Alaska and the Ngatatjara in Australia, see Heth \& Cornell, 1985, pp. 230-235; for a partly different way of place name usage among the Seri people in Mexico see also O'Meara, 2016, pp. 145-146). The role of toponyms is frequently emphasized in anthropological studies, and it is typical for nomadic tribes who travel a lot that their (mostly descriptive) toponyms serve as devices for geographical orientation and act as reminders. Orientational procedures and spatial knowledge associated with historical and mythical knowledge are communally taught. This sophisticated knowledge is distilled in toponyms that cover the landscape. In traditional societies, place names are not considered as simple labels, they are semantically dense. Toponyms are not only economical identifying devices in communication, but they also play a key role in the perception and use of land, and they aid the traveller in actual wayfinding (Aporta, 2016). As Jarvenpa and Brumbach explain, "[i]n everyday conversation and thought, the toponyms create a cultural geography of the landscape, situating the $[\ldots]$ hunter or traveller in both cartographic and cultural space" (2016, p. 20). 
Based on these studies, it seems that toponyms play a special role in traditional communities in terms of the organization of the cognitive map and in orientation in general. ${ }^{13}$ This opposes the conviction that people in modern societies do not use toponyms to facilitate spatial orientation but simply to talk about the space. In the case of communities living in close contact with nature and the landscape, toponyms are integrated into the network of the cognitive map in multiple ways and due to the oral transmission of culture this knowledge can most probably be deemed quite uniform for all people; therefore, it may be supposed that within a community toponyms (with a major overlap with the representation of the places) indirectly help with orientation and the organization of the cognitive map. At the same time, I need to mention that there are no specific studies about name awareness in connection with these communities, we may only have assumptions based on the researchers' general impressions and on the fact that members of the traditional community have the same lifestyle, occupation, and as they spend a lot of time together, their spatial knowledge is also similar, just like their name awareness as reflected in their stories. ${ }^{14}$

In order to address this issue, the linguistic, functional-semantic nature of the toponyms used in the community, and the intuitive knowledge, the speakers' name model, are not negligible either. In the already mentioned research project Jett also studied the linguistic structure of Navajo toponyms and found that they are mostly names describing the characteristics of the given place and environment (e.g. Shaqa 'a' Tóhi 'the sunnyside spring' in Canyon de Chelly, Jett, 2011, p. 329), while other types of names appear only in the denominations of settlements, and in their case sometimes there are references to ownership or some event and sometimes there are also borrowings (2011, p. 331, 337; 2014). This kind of organization of the toponymic corpus, with the dominance of transparent descriptive names, is typical of nomadic societies, ${ }^{15}$ as the following examples show: Hast Hantip Quih Iti Iihca 'hill [rock] where there is salt', Xepe Coosot 'sea water that is narrow', Moosni Ooja 'that which sea turtles encircle' in the Seri language (O'Meara, 2016, pp. 137-139); Sépyáldá 'rainy hill', Dóigàuvấudấudéè

${ }_{13}$ Based on this experience, anthropologists and anthropological linguists suppose that place names might have had a similar function in the past too. "Long before the emergence of written language systems and modern conceptions of history, place names served as enduring symbols and mnemonic devices that aided in planning future events and in remembering and imagining past events" (Meadows, 2008, p. 5; Basso, 1996, p. 7).

${ }^{14}$ In some semi-nomadic communities a "gendered landscape" is described: specialized female and male spaces (Jarvenpa, Brumbach, 2016, pp. 28-29) that could contribute to "gendered name awareness". Even so, the dominance of descriptive names characterized both female and male toponomasticons.

15 The descriptive nature of indigenous place names led to the misconception that Native Americans did not have real place names (cf. Bright, 2003, pp. 674-676). 
'place where a river is positioned deep below' in Kiowa (Meadows, 2008, p. 21; for further examples see e.g. Vaarzon-Morel, 2016; Hunn, 1996; for a general overview see Schreyer, 2006). ${ }^{16}$ A name model based on such experience, the descriptive nature of the names also facilitates the association of the name with a place. ${ }^{17}$ Even though the name-giver may in theory choose from numerous other features when naming a given place, in these communities it is mostly the most striking external attribute that appears in the name. If the name users are socialized by experiencing that toponyms provide actual information about the landscape and that they are not only semantically opaque designators of the place, this probably results in a more analytical processing of names. At the same time, as a consequence of such an attitude towards names, the semantic content embedded in the name directs the spatial attention of name users and the association of the name with an object is facilitated by the recognition of the motivation, an important attribute. ${ }^{18}$ (Of course, we might also observe this kind of attitude towards names in modern societies to some extent but it could not be considered such an essential feature as in traditional cultures.)

The differences in world view, perception and interaction with the landscape can be quite well illustrated with the comparison of Tlingit and English (EuroAmerican) place names of Glacier Bay in Alaska. More than $90 \%$ of native names refer to biological and/or topographical features of the land and sea, and many of them contain a detailed description of the place, because of the grammatical features of the language, e.g. Anax Kuyaawal 'ix' $i$ Yé 'where the glacier ice broke through', Loolxooshaa 'mountain amidst the Fireweed'. English toponyms, on the other hand, can be characterized by dominating honorific naming practice in this region, e.g. La Perouse Glacier, Dixon Entrance, Muir Inlet (Thornton, 1995,

${ }^{16}$ Hercus and Simpson (2002, pp. 16-19) analyzed the semantic content of place names in Central Australia and found that there are a few basic name categories: a) names describing physical features of the environment (mostly vegetation), b) names referring to ancestral beings, c) complex names referring to both ancestral beings and the environment.

${ }^{17}$ The special navigation-helping role of descriptive names was also found in a psychological experiment. Meilinger and colleagues pointed out that descriptive names were easily built in cognitive map in a new environment and aided orientation in a later experimental situation. In other words, "correspondence between verbal and non-verbal memory traces by learning meaningful labels facilitates later retrieval" (Meilinger et al., 2016, p. 6). In the case of arbitrary labels, however, retrieval was found to be inhibited.

${ }^{18}$ Traditional societies with traditional lifestyle are disappearing gradually. The younger generations' worldview is becoming more and more similar to that of Western societies. It is examined thoroughly in Native American communities and it is general elsewhere also. Tuck-Po found a considerable degree of ignorance of local toponymy among young Penan people in Southeast Asia. When he asked the name of rivers, one young Penan man answered that "there are so many rivers over there-how am I supposed to tell one river from another?” (2016, p. 248, cf. Reszegi, 2020b). 
pp. 295-296, 298). These are transparent names, but they usually do not reflect the features of the places.

\section{CONCLUSIONS}

Based on this short overview, it seems that modern and traditional societies differ considerably in their name-usage patterns, just as in their experience of names, name models, and as a result, in the relationship between toponyms and their cognitive maps. In general, we may claim that in the case of traditional societies living close to nature speakers have a different type of knowledge and expectations of toponyms: these linguistic elements reliably reflect the features of the place designated by them. As a result, we can recognize a significant role of toponyms in the formation of the cognitive map. By contrast, in modern societies (due to the lack of name awareness and the dominance of the referential nature of names), toponyms do not have such a mapping function, or at least, in the case of most individuals, such a role is far less important.

In view of the above, two preliminary conclusions can clearly be drawn in connection with linguistic relativity. 1 . The name model created on the basis of the mental representation of names is partly language- and culture dependent. ${ }^{19}$ 2. This relationship is two-directional and the name model itself also has an influence on cognition. The speaker's knowledge of how reliably toponyms correlate with the actual features of the landscape, or whether they should only be considered as forms identifying an area, is culturally determined. This, in turn, influences the extent to which we may rely on them in structuring space and in building a cognitive map. Thus we may also talk about linguistic relativity in connection with toponyms, while its extent depends on the individual's general knowledge and experience of names.

Contrary to all the referred studies and research results, we have to bear in mind the complexity of this topic, that is, to make generalized statements on this question, more research is needed. I hope, however, that my work will serve as a good foundation for further study.

\section{REFERENCES}

Aporta, C. (2016). Markers in Space and Time: Reflections on the Nature of Place Names as Events in the Inuit Approach to the Territory. In W.A. Lovis \& R. Whallon (Eds.), Marking the Land: Hunter-Gatherer Creation of Meaning in their Environment (pp. 67-88). New York: Routledge.

19 The time element might be referred to as a component of this complex relationship also, with time, name model may change. 
Balázs, G. (2008). A helynevek antropológiai nyelvészeti szempontból [Toponyms from the point of view of anthropological linguistics]. Magyar Nyelvör, 132, 348-354.

Basso, K. (1988). "Speaking with names": language and landscape among Western Apache. Cultural Anthropology, 3(2), 99-130.

Blevins, J.P., \& Blevins, J. (2009). Introduction: Analogy in Grammar. In J.P. Blevins, \& J. Blevins (Eds.), Analogy in Grammar: Form and Acquisition (pp. 1-12). Oxford: Oxford University Press.

Boroditsky, L. (2006). Linguistic relativity. In L. Nadel (Ed.), Encyclopedia of cognitive science (pp. 917-921). London: MacMillan Press. https://doi.org/10.1002/0470018860.s00567 (Retrieved from http://lera.ucsd.edu/papers/linguistic-relativity.pdf).

Boroditsky, L. (2009, June 11). How does our language shape the way we think. Edge. https:// www.edge.org/conversation/lera boroditsky-how-does-our-language-shape-the-way-we-think

Boroditsky, L. (2011). How language shapes thought. Scientific American, 304(2), 62-65.

Bright, W. (2003). What IS a name? Reflections on Onomastics? Language and Linguistics, 4(4), $669-681$.

Burenhult, N., \& Levinson, S.C. (2008). Language and landscape: a cross-linguistic perspective. Language Science, 30, 135-150.

Bybee, J.L., \& Slobin, D.I. (1982). Rules and schemas in the development and use of English past tense. Language, 58, 265-289.

Coates, K.S. (2004). A Global History of Indigenous Peoples. Struggle and Survival. Houndmills: Palgrave Macmillan.

Cogos, S., Roué, M., \& Roturier, S. (2017). Sami place names and maps: transmitting knowledge of a cultural landscape in contemporary contexts. Arctic, Antarctic, and Alpine Research, 49(1), 43-51.

Downs, R.M., \& Stea, D. (2011). Cognitive Maps and Spatial Behaviour: Process and Products. In M. Dodge, R. Kitchin \& C. Perkins (Eds.), The Map Reader: Theories of Mapping Practice and Cartographic Representation (pp. 311-317). John Wiley \& Sons Ltd.

Dú11, A. (2007). A környezet hatása a tanulási folyamatokra: környezet és alkalmazkodás [The influence of the environment on learning processes: environment and adaptation]. In V. Csépe, M. Györi, A. Ragó (Eds.), Általános pszichológia 2. Tanulás —emlékezés - tudás (pp. 111-153). Budapest: Osiris Kiadó.

Ekstrom, A.D., Kahana, M.J., \& Caplan, J.B. (2003). Cellular networks underlying human spatial navigation. Nature, 425(6954), 184-188.

Francis, H., \& Kelley, K. (2005). Traditional Navajo maps and wayfinding. American Indian Culture and Research Journal, 29(2), 85-111.

Győrffy, E. (2015). A névismeret és a kognitív térkép [Name awareness and cognitive maps]. Magyar Nyelvjárások, 52, 5-33.

Győrffy, E. (2017). Empíria és elmélet a helynévhasználat vizsgálatában [Empiricism and theory in investigation of place-name usage] [Unpublished habilitation dissertation]. University of Debrecen.

Gyselinck, V., \& Meneghetti, C. (2011). The role of spatial working memory in understanding verbal descriptions: A window onto the interaction between verbal and spatial processing. In A. Vandierendonck, A. Szmalec (Eds.), Current issues in memory. Spatial working memory (pp. 159-180). Psychology Press.

Harris, C.L. (2006). Language and Cognition. In L. Nadel (Ed.), Encyclopedia of Cognitive Science (pp. 1-6). John Wiley \& Sons Ltd. https://doi.org/10.1002/0470018860.s00559

Haviland, W.A., Prins, H.E.L., Walrath, D., \& McBride, B. (2011). Anthropology. The Human Challange. Wadsworth.

Hercus, L., \& Simpson, J. (2002). Indigenous Place Names: An Introduction. In L. Hercus, F. Hodges \& J. Simpson (Eds.), The Land is a Map: Place Names of Indigenous Origin in Australia (pp. 1-23). Canberra: Pandanus Books in association with Pacific Linguistics. 
Heth, C.D., \& Corne1l, E.H. (1985). A Comparative Description of Representation and Processing During Search. In H.M. Wellman (Ed.), Children's Searching. The Development of Search Skill and Spatial Representation (pp. 215-249). Hillsdale: Erlbaum.

Hoffmann, I. (1993). Helynevek nyelvi elemzése [Linguistic analysis of place names]. Debrecen: Kossuth Lajos Tudományegyetem.

Hoffmann, I. (2012). Funkcionális nyelvészet és helynévkutatás [Functional linguistics and onomastics]. Magyar Nyelvjárások, 50, 9-26.

Hunn, E. (1996). Columbia Plateau Indian place names: What can they teach us? Journal of Linguistic Anthropology, 6(1), 3-26.

Jarvenpa, R., \& Brumbach, H.J. (2016). Initializing the Landscape: Chipewyan Construction of Meaning in a Recently Occupied Environment. In W.A. Lovis \& R. Whallon (Eds.), Marking the Land: Hunter-Gatherer Creation of Meaning in their Environment (pp. 13-44). New York: Routledge.

Jett, S.C. (2011). Landscape embedded in language. The Navajo of Canyon de Chelly, Arizona, and their named places. In D.M. Mark, A.G. Turk, N. Burenhult \& D. Stea (Eds.), Landscape in Language: Transdisciplinary Perspectives (pp. 327-342). Amsterdam: John Benjamins Pub. Co.

Jett, S.C. (2014). Place names as the traditional Navajo's title-deeds, border-alert system, remote sensing, global positioning system, memory bank, and monitor screen. Journal of Cultural Geography, 31(1), 106-113.

Kari, J. (1989). Some principles of Alaskan toponymic knowledge. In M.R. Key, General and Amerindian Ethnolinguistics: In Remembrance of Stanley Newman (pp. 129-149). Berlin: Mouton de Gruyter.

Kelley, K.B., \& Francis, H. (1994). Navajo Sacred Places. Bloomington: Indiana University Press.

Kitchin, R. (1994). Cognitive maps: what are they and why study them? Journal of Environmental Psychology, 14, 1-19.

Kitchin, R., \& Blades, M. (2002). The Cognition of Geographic Space. London, UK: I.B. Taurus Publishers.

Langacker, R.W. (1987). Foundations of cognitive grammar (Vol. 1). Stanford, CA: Stanford University Press.

Levinson, S.C., Kita, S., Haun, D.B.M., \& Rasch, B.H. (2002). Returning the tables: Language affects spatial reasoning. Cognition, 84, 155-188.

Lörincze, L. (1947). Földrajzineveink élete [Life of toponyms]. Budapest: Teleki Pál Tudományos Intézet Néptudományi Intézete.

Lovis, W.A., \& Whallon, R. (Eds.). (2016). Marking the Land: Hunter-Gatherer Creation of Meaning in their Environment. (Routledge Studies in Archaeology). New York: Routledge.

Lukács, Á., \& Szamarasz, V.Z. (2014). Téri nyelv [Spatial language]. In Á. Lukács \& C. Pléh (Eds.), Pszicholingvisztika (Vol. 2, pp. 877-917). Budapest: Akadémiai Kiadó.

Lukács, Á., Pléh, C., Kas, B., \& Thuma, O. (2014). A szavak mentális reprezentációja és az alaktani feldolgozás [Mental represenatation of words and morphological processing]. In Á. Lukács \& C. Pléh (Eds.), Pszicholingvisztika (Vol. 1, pp. 167-250). Budapest: Akadémiai Kiadó.

Maffi, L. (2002). Linking Language and Environment: a Coevolutionary Perspective. In C.L. Crumley (Ed.), New Directions in Anthropology and Environment: Intersections (pp. 24-48). Lanham: Altamira Press.

Meadows, W.C. (2008). Kiowa Ethnogeography. Austin: University of Texas Press.

Meilinger, T., Schulte-Pelkum, J., Frankenstein, J., Hardiess, G., Laharnar, N., Mallot, H.A., \& Bülthoff, H.H. (2016). How to Best Name a Place? Facilitation and Inhibition of Route Learning Due to Descriptive and Arbitrary Location Labels. Frontiers in Psychology, 7. https:// doi.org/10.3389/fpsyg.2016.00076

Nánay, B. (2000). Elme és evolúció: Az elmefilozófia és a kognitív tudomány evolúciós megközelitése [Mind and evolution: Evolutional approach of mind philosophy and cognitive science]. Budapest: Kávé Kiadó. 
Nelson, R. (1983). The Athabaskans: People of the Boreal Forest. Fairbanks, AK: University of Alaska Museum.

Nyström, S. (2016). Names and Meaning. In C. Hough (Ed.), The Oxford Handbook of Names and Naming (pp. 39-51). Oxford: Oxford University Press.

Oetelaar, G.A. (2016). Places on the Blackfoot Homeland Markers of Cosmology, Social Relationships and History. In W.A. Lovis \& R. Whallon (Eds.), Marking the Land: HunterGatherer Creation of Meaning in their Environment (pp. 45-66). New York: Routledge.

O'Keefe, J. (1976). Place units in the hippocampus of the freely moving rat. Experimental Neurology, 51, 78-109.

O'Meara, C.K. (2016). Physical and Linguistic Marking of the Seri Landscape. In W.A. Lovis \& R. Whallon (Eds.), Marking the Land: Hunter-Gatherer Creation of Meaning in their Environment (pp. 133-151). New York: Routledge.

Pederson, E. (2007). Cognitive Linguistics and Linguistic Relativity. In D. Geeraerts \& H. Cuyckens (Eds.), The Oxford Handbook of Cognitive Linguistics (pp. 1012-1044). Oxford: Oxford University Press.

Regier, T. (1996). The Human Semantic Potential: Spatial Language and Constrained Connectionism. Cambridge, MA: The MIT Press.

Reszegi, K. (2009). A tulajdonnevek mentális reprezentációjáról [On the mental representation of proper names]. Névtani Értesitö, 31, 7-16.

Reszegi, K. (2012). Cognitive Approach to Hungarian Toponymy. Onoma, 47, 367-379.

Reszegi, K. (2015). A névközösség fogalmához. Névközösségek napjainkban és a régiségben [On the concept of name community. Name communities today and in the past]. Helynévtörténeti Tanulmányok, 11, 165-176.

Reszegi, K. (2018). Helynevek - térszemlélet - mentális térkép. A nyelv, a helynevek és a tér összefüggései [Toponyms - spatial perception - mental map. The relationships of language, toponyms and space]. Magyar Nyelv, 114, 169-184.

Reszegi, K. (2020a.) Name - Culture - Identity. The Semantic Structure of Names. In L. Caiazzo, R. Coates \& M. Azaryahu (Eds.), Naming, Identity and Tourism (pp. 154-167). Newcastle upon Tyne: Cambridge Scholars Publishing.

Reszegi, K. (2020b.) Cognitive Maps and Toponyms in a Broadening Geographical Horizon. In O. Felecan (Ed.), Proceedings of the Fifth International Conference on Onomastics Name and Naming: Multiculturalism in Onomastics. In print.

Schemmel, M. (2016). Towards a Historical Epistemology of Space. Introduction. In M. Schemmel (Ed.), Spatial Thinking and External Representation. Towards a Historical Epistemology of Space (pp. 1-34). Berlin: Max Planck Research Institution.

Schreyer, C. (2006). "What You See is Where You Are": An Examination of Native North American Place Names. In E.C. Robertson, J.D. Seibert, D.C. Fernandez \& M.U. Zender (Eds.), Space and Spatial Analysis in Archeology (pp. 227-232). New Mexico: University of Calgary Press.

Thiering, M. (2015). Spatial Semiotics and Spatial Mental Models: Figure-Ground Asymmetries in Language. De Gruyter Mouton.

Thiering, M., \& Schiefenhövel, W. (2016). Spatial Concepts in Non-Literate Societies: Languauge and Practice in Eipo and Dene Chipewyan. In M. Schemmel (Ed.), Spatial Thinking and External Representation. Towards a Historical Epistemology of Space (pp. 35-92). Berlin: Max Planck Research Institution.

Thornton, T.F. (1995). Tlingit and Euro-American Toponymies in Glacier Bay. In D.R. Engstrom (Ed.), Proceedings of the Third Glacier Bay Science Symposium (pp. 294-301). Anchorage, AK: U.S. Department of the Interior, National Park Service.

Tolcsvai Nagy, G. (2008). A tulajdonnév jelentése [The meaning of proper names]. In A. Bölcskei \& I.N. Császi (Eds.), Név és valóság (pp. 30-41). Budapest: Károli Gáspár Református Egyetem Magyar Nyelvtudományi Tanszék. 
Tomase1lo, M. (1999). The Cultural Origins of Human Cognition. Cambridge, MA: Harvard University Press.

Tomase1lo, M. (2009). The usage-based theory of language acquisition. In E.L. Bavin (Ed.), The Cambridge Handbook of Child Language (pp. 69-87). Cambridge University Press.

Tuggy, D. (2005). Cognitive Approach to Word-Formation. In P. Štekauer \& R. Lieber (Eds.), Handbook of Word-Formation (pp. 233-265). Dordrecht: Springer.

Tuck-Po, L. (2016). Signaling Presence. How Batek and Penan Hunter-gatherers in Malaysia Mark the Landscape. In W.A. Lovis and R. Whallon (Eds.), Marking the Land: Hunter-Gatherer Creation of Meaning in their Environment (pp. 231-260). New York: Routledge.

Varga, Z. (2020). Helynév-szociológiai vizsgálatok két romániai magyar településen [Socio-onomastic studies in two Hungarian settlements in Romania] [Unpublished doctoral dissertation]. University of Debrecen.

Vaarzon-More1, P. (2016). Continuity and Change in Warlpiri Practices of Marking the Landscape. In W.A. Lovis \& R. Whallon (Eds.), Marking the Land: Hunter-Gatherer Creation of Meaning in their Environment (pp. 201-230). New York: Routledge.

Valentine, T., Brennen, T., \& Brédart, S. (1996). The Cognitive Psychology of Proper Names. On the importance of being Ernest. London-New York: Routledge.

Webster, A.K. (2017). Why Tséhootsooí Does Not Equal "Kit Carson Drive": Reflections on Navajo Place Names and the Inequalities of Language. Anthropological Linguistics, 59, 239-262.

\section{SUMMARY}

\section{TOPONYMS AND SPATIAL REPRESENTATIONS}

This paper addresses an interesting issue in name theory, specifically the relationship between toponyms and spatial representations, as well as the cultural differences manifesting themselves in connection with these. Studies have shown that the name model (a general knowledge of names) created based on the mental representation of names is partly language and culture dependent. Thus, the knowledge of the speaker on how reliably the toponyms correlate with the actual features of the landscape or whether they should only be considered as labels identifying an area is culturally determined. This, in turn, influences the extent to which name-users may rely on them in structuring space and in creating a cognitive map. 